\title{
Kendala Berkomunikasi yang Dihadapi oleh Tenaga Profesional Penutur Bahasa Jepang di Perusahaan Jepang
}

\author{
Lufi Wahidati $^{*}$ ), Fatmawati Djafri ${ }^{2}$ \\ 1,2Program Studi DIII Bahasa Jepang, Sekolah Vokasi, Universitas Gadjah Mada \\ *Corresponding author email: lufi.wahidati@ugm.ac.id
}

Direview: 15 Desember 2020, Direvisi: 8 Februari 2021, 27 Februari 2021, Diterima: 27 Februari 2021

\begin{abstract}
Abstrak
Dalam rangka penyelenggaraan program pelatihan bahasa asing untuk komunikasi bisnis, dilakukan survei pendahuluan terkait kendala berkomunikasi yang dihadapi oleh staf Indonesia penutur bahasa Jepang. Penelitian ini berusaha untuk mengidentifikasi jenis kesulitan, situasi-situasi yang sering menimbulkan kesulitan berkomunikasi, serta penyebab terjadinya permasalahan komunikasi menurut para tenaga profesional penutur bahasa Jepang yang bekerja di perusahaan Jepang. Penelitian ini menggunakan metode campuran (mixed method) antara penelitian kualitatif dan kuantitatif. Penelitian diawali dengan pengumpulan data menggunakan angket. Simpulan sementara yang diperoleh dari hasil analisis angket kemudian diuji kembali melalui wawancara mendalam (in-depth interview) pada beberapa responden yang terpilih. Hasil wawancara dan data dari angket kemudian dianalisis kembali untuk mendapatkan simpulan akhir dari penelitian. Berdasarkan analisis, disimpulkan bahwa staf Indonesia penutur bahasa Jepang terutama mengalami permasalah berkomunikasi menggunakan bahasa Jepang saat harus melakukan komunikasi secara spontan tanpa adanya persiapan. Kendala tersebut banyak terjadi pada saat diskusi, rapat, juga komunikasi melalui telpon. Terdapat faktor internal dan faktor eksternal yang menyebabkan terjadinya kendala berkomuniasi dengan penutur jati bahasa Jepang. Faktor internal meliputi faktor penguasaan bahasa dan faktor perbedaan budaya, sedangkan faktor eksternal terjadi karena perbedaan budaya kerja di Indonesia dan di Jepang.
\end{abstract}

Kata kunci: kesulitan berkomunikasi; komunikasi bisnis; bahasa Jepang 


\begin{abstract}
(Communication problems faced by Japanese-speaking staff in Japanese company) In order to develop a Japanese-language training program for business communication, a survey was conducted exploring the communication problems faced by the Japanese spoken Indonesian staffs when they were communicating with the Japanese native speakers in a Japanese company. The research used a mix method between qualitative and quantitative research. The data were collected by using a questionnaire and through in-depth interviews with several selected respondents. The results of the interviews and the data from the questionnaire were then re-analyzed to get the final conclusion. Based on the analysis, it was concluded that Japanese-spoken Indonesian staff especially faced problems communicating using Japanese when they had to communicate spontaneously or without making any preparation. Many of these obstacles found during discussions, meetings, as well as in a line-telephone conversation. There are internal factors and external factors that cause problems communicating with Japanese native speakers. Internal factors are the language mastery factors and cultural difference factors, while external factors occur due to the working culture differences in Indonesia and in Japan.
\end{abstract}

Keywords: communication problem; business communication; Japanese

\title{
PENDAHULUAN
}

Jumlah perusahaan PMA Jepang di Indonesia meningkat dewasa ini. Jepang yang sedang menghadapi aging society, untuk menopang perekonomiannya mau tidak mau harus menyerap tenaga kerja asing untuk bekerja di Jepang atau membuka cabang perusahaan di luar negeri, terutama di wilayah ASEAN seperti Indonesia, Vietnam, atau Thailand yang memiliki jumlah angkatan kerja usia produktif yang besar.

Kerja sama ekonomi dengan Jepang merupakan salah satu kunci penting untuk meningkatkan laju pertumbuhan ekonomi di Indonesia. Foreign direct investment dapat meningkatkan penerimaan pajak di Indonesia serta memberikan kesempatan kerja bagi tenaga kerja di Indonesia (Hemanona \& Suharyono, 2017). Salah satu unsur penunjangnya yaitu dengan meningkatkan kualitas SDM yang memiliki kompetensi komunikasi bahasa Jepang yang mumpuni agar dapat menjadi jembatan komunikasi antara Indonesia dan Jepang.

Sebagaimana yang diungkapkan oleh Pratama (2015), sebuah perusahaan Indonesia yang bergerak di bidang konstruksi sering kali 
mengalami jalan buntu pada proses negosiasi dengan perusahaan Jepang karena kendala bahasa. Terlebih lagi saat harus bernegosiasi dengan customer dari perusahaan Jepang yang tidak menguasai bahasa Indonesia maupun bahasa Inggris. Di lain sisi, perusahaan Jepang yang didirikan di Indonesia juga sangat memerlukan staf berbahasa Jepang untuk menjadi jembatan komunikasi antara pihak manajemen Jepang dengan karyawan Indonesia. Berdasarkan fakta-fakta tersebut, sangat jelas bahwa tenaga profesional yang memiliki kompetensi bahasa Jepang sangat dibutuhkan untuk kelancaran kerja sama ekonomi antara Indonesia dengan Jepang.

Tenaga kerja profesional yang bekerja di perusahaan Jepang sedikit atau banyak pasti akan dihadapkan pada situasi yang mengharuskan mereka bersinggungan secara langsung dengan orang Jepang. Adanya perbedaan latar belakang budaya antara Indonesia dan Jepang, khususnya budaya kerja, menyebabkan tenaga kerja profesional berbahasa Jepang sedikit banyak pasti mengalami masalah ketika menjalankan tugasnya di perusahaan Jepang. Berdasarkan jajak pendapat yang dilakukan oleh Program Studi Bahasa Jepang Sekolah Vokasi UGM terhadap beberapa perusahaan Jepang di Indonesia yang merekrut staf penutur bahasa Jepang lulusan universitas di Indonesia, kendala terbatasnya kemampuan berkomunikasi dalam bahasa asing menjadi salah satu penyebab kegagalan para staf dalam masa percobaan. Oleh karena itu, kebutuhan akan pengembangan kurikulum pendidikan vokasional di bidang bahasa Jepang untuk mencetak SDM yang sesuai dengan kebutuhan industri menjadi sangat mendesak.

Nisfullayli (2018) dalam penelitiannya telah memetakan tugas/ pekerjaan dalam ranah komunikasi bisnis menggunakan bahasa Jepang yang dilakukan oleh para alumni sastra dan bahasa Jepang di perusahaan Jepang. Jenis pekerjaan menggunakan komunikasi tulis di antaranya adalah menulis surel, penerjemahan tertulis, menulis pesan singkat, memo, mengisi form, membuat laporan, menyusun dokumen, dan membuat notulensi. Sementara itu, pekerjaan yang menggunakan komunikasi lisan meliputi penerjemahan 
lisan, komunikasi melalui telepon, handling guest, membuat janji, meeting, menanggapi klien, dan melakukan presentasi.

Berkaitan dengan soft skill yang diperlukan untuk bekerja di perusahaan Jepang, Dwiwardani dan Wahidati (2019) mengidentifikasi bahwa menurut para lulusan program sastra atau bahasa Jepang yang bekerja di perusahaan Jepang, keterampilan berkomunikasi merupakan keterampilan yang paling ingin mereka kembangkan karena mereka tidak jarang menemui kendala berkomunikasi di tempat kerja. Kendala dalam berkomunikasi pasti akan berpengaruh pada jalannya kegiatan ekonomi di sebuah perusahaan.

Untuk mengembangkan kurikulum pendidikan vokasional bahasa Jepang yang sesuai dengan kebutuhan dan dapat menurunkan resiko terjadinya permasalahan berkomunikasi di dunia kerja, perlu dilakukan identifikasi terhadap kendala berkomunikasi yang dihadapi oleh para penutur bahasa Jepang di dunia kerja. Sejauh penelusuran penulis, identifikasi mendalam tentang jenis kendala, situasi serta faktor penyebab terjadinya kendala berkomunikasi belum banyak dilakukan, sehingga sulit menentukan materi pembelajaran bahasa Jepang untuk komunikasi bisnis yang sesuai dengan kebutuhan di dunia kerja. Oleh karena itu, penelitian ini dilakukan untuk mengidentifikasi tiga hal, yaitu: 1) jenis kendala/permasalahan dalam berkomunikasi, 2) situasi-situasi yang sering menimbulkan permasalahan dalam komunikasi, serta 3) faktor-faktor yang mempengaruhi terjadinya kendala-kendala yang dihadapi staf penutur bahasa Jepang dalam berkomunikasi dengan ekspatriat Jepang di perusahaan Jepang.

\section{METODE PENELITIAN}

Penelitian ini merupakan penelitian dengan metode campuran (mixed method). Penelitian diawali dengan pengumpulan data menggunakan angket 
dengan responden staf Indonesia penutur bahasa Jepang yang tengah bekerja di perusahaan Jepang.

Pada umumnya karyawan baru harus mengikuti masa percobaan minimal 3 bulan di perusahaan. Masa percobaan juga merupakan masa yang diperlukan karyawan baru untuk beradaptasi dengan lingkungan kerja serta menyesuaikan diri dengan pekerjaan yang dilakukannya. Vanuxem (2017) mengungkapkan bahwa setidaknya seorang pegawai membutuhkan waktu 3 hingga 6 bulan untuk dapat beradaptasi dengan pekerjaan baru.

Berkaitan dengan kemampuan bahasa Jepang, pada umumnya perusahaan Jepang menerapkan standar minimum JLPT N3 sebagai syarat untuk mendaftar pekerjaan di perusahaan mereka. Pada level ini, seseorang dianggap mampu mendengarkan dan memahami percakapan yang koheren dalam situasi sehari-hari, berbicara dengan kecepatan yang hampir alami, dan secara umum mampu mengikuti isi pembicaraan serta memahami hubungan di antara orang-orang yang terlibat (Japan Foundation, n.d.).

Berdasarkan hal tersebut, ditentukan persyaratan responden sebagai berikut:

1. minimal telah bekerja di perusahaan Jepang selama 6 bulan,

2. memiliki kemampuan berkomunikasi setara dengan JLPT N3 atau lebih tinggi,

3. secara aktif menggunakan bahasa Jepang secara lisan maupun tulisan saat menjalankan pekerjaannya, dan

4. secara berkala melakukan komunikasi langsung dengan orang Jepang, baik atasan, rekan kerja, maupun klien.

Keempat persyaratan tersebut ditetapkan dengan anggapan bahwa seseorang yang memenuhi kriteria tersebut telah memiliki pengalaman melakukan interaksi dengan penutur jati (native speaker) bahasa Jepang yang cukup.

Pertanyaan dalam angket meliputi pertanyaan mengenai kesulitan berkomunikasi berdasarkan media komunikasi (lisan dan tulis). Responden 
juga diminta untuk menuliskan kendala berkomunikasi, situasi saat terjadinya permasalahan, serta faktor penyebab terjadinya permasalahan berkomunikasi dengan penutur jati bahasa Jepang berdasarkan pengalaman mereka di tempat kerja. Jawaban responden pada angket dianalisis kemudian dikategorikan berdasarkan pertanyaan-pertanyaan yang berusaha dijawab pada penelitian ini. Berdasarkan data yang terkumpulkan, kemudian dilakukan wawancara terhadap dua responden terpilih untuk mengonfirmasi data tersebut. Setelah seluruh data terkumpul, dilakukan analisis dan hasil analisis disajikan secara deskriptif menggunakan tabel dan narasi.

\section{HASIL DAN PEMBAHASAN}

\section{Deskripsi Data Penelitian}

Tabel 1. Profil demografi responden

(Sumber: Data penelitian)

\begin{tabular}{|c|c|c|c|c|c|}
\hline No & $\begin{array}{l}\text { Profil demografi } \\
\text { responden }\end{array}$ & Persentase & No & $\begin{array}{l}\text { Profil } \\
\text { demografi } \\
\text { responden }\end{array}$ & tase \\
\hline \multirow[t]{5}{*}{1} & Usia & & 5 & Bidang kerja & \\
\hline & $21-25$ & $44 \%$ & & interprater/penerjemah & $38 \%$ \\
\hline & $26-30$ & $44 \%$ & & pemasaran/marketing & $13 \%$ \\
\hline & $31-35$ & $4 \%$ & & sekretaris/administrasi & $7 \%$ \\
\hline & $35-40$ & $7 \%$ & & Produksi & $7 \%$ \\
\hline \multirow[t]{3}{*}{2} & Jenis kelamin & & & Purchasing & $4 \%$ \\
\hline & Perempuan & $73 \%$ & & personalia/HR/GA & $4 \%$ \\
\hline & laki-laki & $27 \%$ & & Hospitality & $4 \%$ \\
\hline \multirow[t]{3}{*}{3} & Lokasi Perusahaan & & & lain-lain & $22 \%$ \\
\hline & Indonesia & $87 \%$ & 6 & Level JLPT & \\
\hline & Jepang & $13 \%$ & & JLPT N1 & $9 \%$ \\
\hline \multirow[t]{5}{*}{4} & Pendidikan terakhir & & & JLPT N2 & $51 \%$ \\
\hline & $\mathrm{S} 2$ & $9 \%$ & & JLPT N3 & $40 \%$ \\
\hline & S1 & $73 \%$ & 7 & Pengalaman kerja di perusahaan Jepang & \\
\hline & D3 & $18 \%$ & & $\leq 5$ tahun & $71 \%$ \\
\hline & & & & $\geq 5$ tahun & $29 \%$ \\
\hline
\end{tabular}

Angket disebarkan kepada responden secara online menggunakan Google Form. Hingga akhir proses distribusi angket, didapatkan 45 responden. Berdasarkan tabel 1, dapat diketahui bahwa sebagian besar responden masih berusia 21-25 tahun dan antara 26-30 tahun, yaitu masingmasing sebanyak 44\%. Jumlah ini menunjukkan bahwa sebagian besar responden belum lama bekerja di perusahaan Jepang. Hal itu juga dibuktikan 
Journal of Japanese Language Education and Linguistics

Volume 5 No. 1, 2021, 12-30

e-ISSN: 2615-0840 p-ISSN: 2597-5277

DOI: https://doi.org/10.18196/jilel.v5i1.10523

https://journal.umy.ac.id/index.php/ijlel/issue/view/734

dengan tercatatnya $71 \%$ responden yang menyatakan bahwa pengalaman bekerja mereka masih kurang dari atau sama dengan 5 tahun, dan hanya $29 \%$ responden yang telah bekerja lebih dari 5 tahun. Sedangkan rata-rata masa kerja responden adalah 3,9 tahun.

Berkaitan dengan level kemampuan bahasa Jepang, hanya terdapat empat responden (9\%) yang telah lulus JLPT N1. Sementara itu, jumlah responden yang memiliki sertifikat JLPT N2 adalah 51\% dan responden bersertifikat JLPT N3 adalah sebanyak 40\%. Untuk menjelaskan tentang level JLPT responden, disusunlah tabel 2, tabel 3, dan tabel 4.

Tabel 2. Persentase pemilik sertifikat JLPT berdasarkan jenjang pendidikan (Sumber: Data penelitian)

\begin{tabular}{cccc}
\hline Level JLPT & D3 & S1 & S2 \\
\hline N1 & $13 \%$ & $6 \%$ & $25 \%$ \\
N2 & $38 \%$ & $61 \%$ & $0 \%$ \\
N3 & $50 \%$ & $33 \%$ & $75 \%$ \\
Jumlah & 8 & 33 & 4 \\
\hline
\end{tabular}

Tabel 2 menunjukkan persentase pemilik sertifikat JLPT berdasarkan jenjang pendidikan responden. Dari tabel 2 dapat dikatakan bahwa terdapat perbedaan yang signifikan antara level JLPT yang dimiliki lulusan jenjang S1 dan D3 dengan konsentrasi bahasa/sastra/pendidikan bahasa Jepang. Responden yang memiliki sertifikat JLPT N2, lulusan program S1 sebesar 61\%, sedangkan lulusan program D3 hanya 38\%. Sebaliknya, persentase responden lulusan D3 yang memiliki sertifikat JLPT N3 adalah 50\%, lebih tinggi dari pada lulusan S1 (33\%). Dapat diasumsikan bahwa lama masa studi juga berpengaruh terhadap kemampuan bahasa Jepang karena mahasiswa S1 memiliki kesempatan belajar bahasa Jepang di universitas lebih lama jika dibandingkan mahasiswa di jenjang D3. Meskipun demikian, terdapat pula lulusan D3 yang telah lulus JLPT N2 dan N1. Hal tersebut menunjukkan bahwa jenjang pendidikan tidak berpengaruh secara mutlak 
terhadap kemampuan bahasa Jepang seseorang. Empat responden (satu orang lulusan D3, dua orang lulusan S1, dan satu orang lulusan S2) yang bersertifikat JLPT N1 memiliki pengalaman tinggal di Jepang saat masih berstatus mahasiswa, dan dua responden di antaranya saat ini bekerja di Jepang. Pengalaman tinggal di Jepang juga memiliki pengaruh signifikan pada kemampuan berkomunikasi dalam bahasa Jepang dan pengetahuan tentang budaya Jepang.

Tabel 3 dan tabel 4 disusun untuk melihat kaitan antara level JLPT dengan masa kerja responden. Tabel 3 menunjukkan sebaran level JLPT responden yang memiliki pengalaman bekerja kurang dari atau sama dengan 5 tahun. Dari tabel 3 dapat diketahui bahwa sebanyak 18 responden (56\%) memiliki sertifikat JLPT N2 dengan rata-rata lama kerja adalah 2,32 tahun. 11 responden (34\%) memiliki sertifikat JLPT N3 dan rata-rata masa kerja 2,06 tahun. Hanya tiga responden yang telah lulus JLPT N1.

Tabel 3. Sebaran level JLPT responden dengan pengalaman kerja $\leq 5$ tahun

\begin{tabular}{ccccccc}
\multicolumn{7}{c}{ (sumber: data penelitian) } \\
\hline Level & \multirow{2}{*}{ Jumlah } & Persentase & $\begin{array}{c}\text { Rata-rata } \\
\text { masa kerja (tahun) }\end{array}$ & \multicolumn{3}{c}{ Jenjang Pendidikan } \\
\cline { 5 - 7 } N1 & 3 & $9 \%$ & 5 & - & 2 & S1 \\
N2 & 18 & $56 \%$ & 2,32 & - & 15 & 3 \\
N3 & 11 & $34 \%$ & 2,06 & 2 & 5 & 4 \\
\hline
\end{tabular}

Tabel 4 menunjukkan sebaran level JLPT dari responden yang telah bekerja lebih dari 5 tahun di perusahaan Jepang. Dari tabel 4, terlihat fakta bahwa sebagian besar responden yang memiliki pengalaman kerja lebih lama justru memiliki sertifikat yang lebih rendah dibandingkan responden yang belum lama bekerja di perusahaan Jepang. Sebanyak 54\% responden dengan rata-rata kerja 7,4 tahun justru hanya memiliki sertifikat JLPT N3, 38\% responden telah bersertifikat JLPT N2, dan hanya satu orang yang telah lulus JLPT N1. 
Tabel 4. Sebaran level JLPT responden dengan pengalaman kerja $\geq 5$ tahun (sumber: data penelitian)

\begin{tabular}{ccccccc}
\hline \multirow{2}{*}{$\begin{array}{c}\text { Level } \\
\text { JLPT }\end{array}$} & \multirow{2}{*}{ Jumlah } & \multirow{2}{*}{ Persentase } & \multirow{2}{*}{$\begin{array}{c}\text { Rata-rata } \\
\text { masa kerja (tahun) }\end{array}$} & \multicolumn{3}{c}{ Jenjang Pendidikan } \\
\cline { 5 - 7 } N1 & 1 & $8 \%$ & 14 & 1 & - & S2 \\
N2 & 5 & $38 \%$ & 6,8 & - & 5 & - \\
N3 & 7 & $54 \%$ & 7,4 & - & 7 & - \\
\hline
\end{tabular}

Berdasarkan analisis data pada tabel 3 dan tabel 4, terdapat beberapa kemungkinan terkait kemampuan dasar bahasa Jepang staf penutur bahasa Jepang. Pertama, lamanya masa kerja tidak menjamin peningkatan kemampuan bahasa Jepang seseorang. Di samping itu, sertifikat JLPT mungkin hanya diperlukan sebagai persyaratan minimum untuk merekrut pegawai baru dan tidak semua perusahaan meminta stafnya untuk mengikuti ujian JLPT yang lebih tinggi setelah mereka bekerja sebagai pegawai tetap.

Kedua, setelah seseorang memiliki karier yang stabil, para staf penutur bahasa Jepang mungkin lebih memprioritaskan untuk meningkatkan keterampilan yang lebih dibutuhkan di tempat kerja, seperti pengetahuan tentang bisnis, manajeman, atau keterampilan lain yang berkaitan dengan bidang usaha di perusahaannya. Berdasarkan wawancara terhadap responden yang telah bekerja lebih dari lima tahun, terungkap bahwa para lulusan program studi pendidikan/sastra/bahasa Jepang memiliki pengetahuan di bidang bisnis yang sangat kurang. Oleh karena itu, mereka lebih fokus untuk mengembangkan pengetahuan terkait bisnis agar dapat meningkatkan performa kinerja mereka daripada mengasah kemampuan bahasa Jepang semata.

Dari kedua kemungkinan di atas, disimpulkan bahwa alangkah baiknya apabila pembelajar bahasa Jepang telah lulus JLPT N2 selagi masih duduk di bangku perkuliahan. Semakin tinggi kemampuan dasar bahasa Jepang yang dipoles sebelum lulus kuliah, semakin memudahkan seseorang 
untuk mengembangkan kariernya di dunia kerja. Masa studi 4 tahun terbukti lebih menguntungkan pembelajar bahasa Jepang karena mereka memiliki kesempatan belajar serta dapat memanfaatkan fasilitas pendukung di perguruan tinggi lebih lama, sehingga dapat lebih mudah untuk lulus JLPT N2. Hal ini pun sejalan dengan keputusan pada konggres KPSJI (Konsorsium Program Studi Jepang Se-Indonesia) tahun 2017 di Surabaya, yaitu bahwa capaian pembelajaran lulusan program jenjang sarjana (S1) adalah rentang antara JLPT N3 dan JLPT N2, sedangkan untuk jenjang D3 adalah JLPT N3. Dengan adanya perbedaan target kompetensi lulusan yang ingin dicapai, tentunya berpengaruh terhadap pengembangan kurikulum pada jenjang D3 dan S1.

\section{Kendala Berkomunikasi Penutur Bahasa Jepang di Perusahaan Jepang}

\section{Situasi yang sering menyebabkan permasalahan bagi staf penutur bahasa} Jepang

Pada penelitian ini, responden diminta untuk menjelaskan pada situasi seperti apa kendala berkomunikasi paling banyak ditemui. Berdasarkan hasil penelitian, hanya dua responden yang mengungkapkan tentang kesulitan penggunaan bahasa Jepang secara tertulis, yaitu saat menerjemahkan dokumen dan saat membuat laporan bulanan. Sementara itu, seluruh responden mengungkapkan mengenai kendala dalam melakukan komunikasi lisan, terutama saat melakukan komunikasi spontan yang tidak dipersiapkan.

Situasi-situasi yang menyebabkan mereka harus mengungkapkan sesuatu secara spontan misalnya adalah pada saat melakukan diskusi atau rapat. Pada saat diskusi, seseorang harus mengeluarkan ideide/pendapatnya terkait sesuatu. Pada situasi seperti itu, sering kali staf penutur bahasa Jepang menemui hal-hal baru sehingga kesulitan untuk memberikan respon atau tanggapan menggunakan bahasa Jepang. 
Staf penutur bahasa Jepang juga sering dimintai untuk menerjemahkan secara lisan secara mendadak oleh staf lokal. Karena melakukan komunikasi tanpa persiapan, sering kali staf penutur bahasa Jepang tidak dapat menyampaikan maksud staf lokal dengan baik dan menimbulkan kesalahpahaman atau ketidakpuasan kedua belah pihak yang dijembatani.

Situasi lain yang mengharuskan staf penutur bahasa Jepang harus melakukan komunikasi secara spontan misalnya adalah saat terjadi suatu masalah yang harus segera diputuskan jalan keluarnya. Saat terjadi masalah, staf penutur bahasa Jepang tidak jarang menghadapi kemarahan dari orang Jepang (baik atasan maupun klien). Situasi seperti ini terutama dirasakan oleh responden yang bekerja sebagai juru bahasa/interpreter. Saat atasan (native speaker) sangat marah terhadap salah satu staf lokal yang dianggap menyebabkan masalah, penerjemah harus dapat menyampaikan maksudnya terhadap staf lokal tanpa menyakiti perasaan kedua belah pihak dan menemukan solusi dari permasalahan yang terjadi. Reaksi staf lokal sangat tergantung kepada kemampuan penerjemah dalam menyampaikan maksud ekspatriat Jepang. Ada staf yang membela diri dengan memberikan alasan terjadinya masalah, ada pula staf yang menyepelekan permasalahan yang terjadi karena menganggap atasannya telah memaklumi kesalahannya padahal sebetulnya atasannya sangat marah. Oleh karena itu, sebagai jembatan antara ekspatriat dari Jepang dengan staf lokal, penerjemah memiliki beban psikologis tersendiri.

Kesulitan berkomunikasi secara spontan juga dirasakan beberapa responden pada saat melakukan komunikasi melalui telepon. Komunikasi melalui telepon memang memaksa pembicara untuk menjelaskan segala sesuatu menggunakan kata-kata secara spontan tanpa bantuan komunikasi non-verbal atau gesture. Pembicara juga tidak dapat melihat ekspresi lawan bicaranya. Hal ini didukung oleh data pada angket yang menunjukkan $29 \%$ responden menyatakan "setuju" dan $11 \%$ mengungkapkan "sangat setuju" 
bahwa komunikasi melalui media telepon dirasa lebih sulit jika dibandingkan komunikasi langsung secara tatap muka juga komunikasi tertulis melalui surel atau pesan singkat/chat melalui aplikasi WhatsApp/Line (lihat tabel 5).

Tabel 5. Kesulitan komunikasi berdasarkan media komunikasi (Sumber: data penelitian)

\begin{tabular}{l|lccccc}
\hline No & \multicolumn{1}{|c}{$\begin{array}{l}\text { Kesulitan komunikasi dengan } \\
\text { atasan/kolega/klien menggunakan bahasa } \\
\text { Jepang berdasar media komunikasi }\end{array}$} & $\begin{array}{c}\text { Sangat } \\
\text { Tidak } \\
\text { Setuju } \\
\mathbf{( \% )}\end{array}$ & $\begin{array}{c}\text { Tidak } \\
\text { Setuju } \\
(\%)\end{array}$ & $\begin{array}{c}\text { Kurang } \\
\text { Setuju } \\
\mathbf{( \% )}\end{array}$ & $\begin{array}{c}\text { Setuju } \\
\text { (\%) }\end{array}$ & $\begin{array}{c}\text { Sangat } \\
\text { Setuju } \\
\text { (\%) }\end{array}$ \\
\hline 1 & $\begin{array}{l}\text { Komuniaksi lisan secara langsung (tatap } \\
\text { muka) sangat sulit. }\end{array}$ & 16 & 38 & 33 & 11 & 0 \\
2 & $\begin{array}{l}\text { Komunikasi lisan via telepon sangat sulit. } \\
\text { Komunikasi tulis via e-mail sangat sulit. }\end{array}$ & 9 & 27 & 24 & 29 & 11 \\
4 & $\begin{array}{l}\text { Komunikasi tulis via sms/WA/Line sangat } \\
\text { sulit. }\end{array}$ & 16 & 58 & 27 & 11 & 4 \\
\hline
\end{tabular}

\section{Faktor penyebab kesulitan berkomunikasi}

Berdasarkan analisis terhadap jawaban responden pada pertanyaan terbuka mengenai kendala yang dirasakan oleh para staf Indonesia penutur bahasa Jepang, terdapat dua faktor yang menyebabkan kendala komunikasi di perusahaan Jepang, yaitu faktor internal dan faktor eksternal.

a. Faktor internal

Yang dimaksud dengan faktor internal adalah faktor-faktor penyebab kesulitan yang timbul dari diri sendiri. Pada faktor internal ini, terdapat dua faktor, yaitu faktor penguasaan bahasa dan faktor perbedaan budaya.

1) Faktor bahasa

Berkaitan dengan masalah bahasa, hal yang paling banyak dikeluhkan oleh responden adalah keterbatasan kosakata dan senmonyougo (kosakata teknis berkaitan dengan bidang tertentu) yang digunakan di perusahaan masing-masing. Hal ini diungkapkan oleh sebanyak 32\% responden. Berdasarkan wawancara yang dilakukan terhadap salah satu responden yang direkrut sebagai interpreter oleh sebuah bank Jepang, pada masa percobaan, responden ditempatkan pada posisi penerjemah dokumen tulis sebelum akhirnya dilibatkan untuk bekerja sebagai interpreter. Pada masa ini, staf 
penutur bahasa Jepang lebih banyak diberi tugas untuk menerjemahkan dokumen-dokumen dibandingkan bertugas sebagai juru bahasa. Pada tahap ini, responden seolah dilatih untuk memahami dan mempelajari istilahistilah khusus yang digunakan pada bidang yang digeluti oleh perusahannya. Sehingga dapat dikatakan pada masa awal kerja, seorang staf penutur bahasa Jepang masih awam dengan istilah-istilah teknis yang digunakan di perusahaannya. Hal ini mungkin terjadi karena istilah-istilah tersebut belum dipelajari saat mereka mempelajari bahasa Jepang di perguruan tinggi. Sehingga staf yang baru direkrut atau yang masa kerjanya belum lama mengalami kesulitan berkomunikasi saat banyak senmonyougo digunakan dalam percakapan.

Kendala bahasa lainnya yaitu kendala pada penggunaan bahasa resmi/bahasa ragam hormat (keigo). Sebanyak 18\% mengungkapkan tentang sulitnya menangkap maksud penutur jati bahasa Jepang saat mereka berbicara menggunakan ragam bahasa hormat.

Selain keterbatasan kosakata dan kesulitan dalam ragam hormat, staf penutur bahasa Jepang juga mengungkapkan mengenai kesulitan yang disebabkan oleh penggunaan dialek (hougen). Terdapat banyak dialek dalam bahasa Jepang. Dalam pendidikan formal, bahasa Jepang yang diajarkan adalah bahasa Jepang standar yang digunakan di distrik Kantou (wilayah Tokyo dan sekitarnya), namun sebetulnya di Jepang, banyak sekali terdapat dialek, misalnya dialek Osaka atau dialek Kyusu. Dialek-dialek ini akan terdengar asing oleh penutur bahasa Jepang yang hanya menguasai bahasa Jepang standar. Hal ini disebabkan karena kosakata yang digunakan dalam bahasa Jepang standar sangat jauh berbeda dengan kosakata pada dialekdialek dari wilayah tertentu. Misalnya kata "terima kasih" dalam bahasa Jepang standar adalah "arigatou gozaimasu". Sedangkan dalam dialek Kansai (di wilayah Osaka atau Kyoto) digunakan ungkapan "ookini" untuk mengungkapkan rasa terima kasih. 
Penggunaan tiga hal yang telah disebutkan (senmonyougo, bahasa ragam formal, dan dialek) oleh penutur jati bahasa Jepang sangat menyulitkan staf penutur bahasa Jepang pada situasi yang mengharuskan mereka melakukan komunikasi spontan tanpa melakukan persiapan. Kurangnya pengetahuan dan penguasaan terhadap tiga hal ini akan mengakibatkan komunikasi tidak terjadi secara efektif. Apabila seorang staf penutur bahasa Jepang kesulitan menangkap maksud pembicara maka dapat menyebabkan kesalahan misalnya terjadi kesalahan dalam menerjemahkan, kesalahan dalam menjalankan instruksi, dan sebaginya. Lebih jauh lagi, kesalahan-kesalahan tersebut akan menimbulkan kesalahpahaman atau konflik antara expatriat Jepang dengan staf lokal.

2) Faktor perbedaan budaya komunikasi

Beberapa faktor internal yang berkaitan dengan perbedaan budaya komunikasi ditemukan dalam data penelitian. Perbedaan budaya komunikasi juga menyebebkan kendala bagi staf penutur bahasa Jepang pada situasi yang mengharuskan dilakukannya komunikasi secara spontan. Visiaty (2020) mengungkapkan bahwa budaya tidak dapat dipisahkan dari bahasa. Perbedaan latar budaya antara pembicara dengan lawan bicara rentan menimbulkan konflik dalam berkomunikasi.

Masyarakat Jepang merupakan masyarakat yang menjunjung tinggi harmoni dalam tatanan sosial sehingga mereka cenderung menghindari konflik dalam kehidupan sehari-hari. Sebagai akibatnya, mereka cenderung mengungkapkan sesuatu secara ambigu (JETRO, 1999). Hal ini sejalan dengan pemikiran Hall (dalam Liliweri, 2016). Menurutnya, Jepang termasuk dalam negara yang memiliki budaya konteks tinggi (high context culture/HCC). Bangsa dengan HCC memiliki kecenderungan untuk mengutamakan relasi personal, sehingga untuk menjaga relasi tersebut, pesan dalam komunikasi tidak dinyatakan secara terbuka (implisit). Mereka juga jarang menyatakan reaksi secara terbuka. Masyarakatnya cenderung 
Journal of Japanese Language Education and Linguistics

Volume 5 No. 1, 2021, 12-30

e-ISSN: 2615-0840 p-ISSN: 2597-5277

DOI: https://doi.org/10.18196/jilel.v5i1.10523

https://journal.umy.ac.id/index.php/jilel/issue/view/734

menggunakan kode-kode pesan yang bermakna ganda melaui slang atau idiom.

Beberapa kendala yang disebabkan oleh perbedaan budaya komunikasi dirasakan oleh responden pada saat rapat, misalnya pada saat ingin menyampaikan ketidaksetujuan terhadap ekspatriat Jepang menggunakan bahasa Jepang. Salah satu responden mengungkapkan hal berikut ini:

Bahasa yang digunakan terlalu sulit terutama untuk fresh graduate seperti saya. Karena perusahaan bergerak di bidang real estate, client saya datang dari berbagai macam industri. Ketika meeting informal/formal dengan klient masih banyak katakata yang tidak saya mengerti. Selain itu, cara pikir native (speaker) dan (staf) lokal sangat berbeda sehingga sering kurang setuju dengan cara atasan, tapi tidak bisa diutarakan. Biasanya iyakan dulu, setelah selesai meeting baru berbicara langsung. (Sumber: data penelitian)

Pada situasi tersebut, staf penutur bahasa Jepang mengungkapkan kendala dalam menyampaikan ketidaksetujuannya terhadap orang Jepang. Ia harus memikirkan posisi lawan bicara dan memerlukan waktu untuk dapat menentukan ungkapan yang sesuai agar tidak menyakiti perasaan lawan bicara saat mengungkapkan pendapatnya.

b. Faktor eksternal

Dalam data penelitian dapat diidentifikasi adanya faktor eksternal penyebab terjadinya kendala berkomunikasi yang dihadapi oleh staf Indonesia penutur bahasa Jepang. Faktor eksternal ini merujuk kepada penyebab timbulnya masalah yang berasal dari luar diri staf penutur bahasa Jepang. Faktor ini ialah perbedaan budaya kerja di Indonesia dan budaya kerja di Jepang secara umum. Misalnya permasalahan yang diungkapkan oleh salah seorang responden sebagai berikut:

Seringkali saat muncul perubahan schedule/rencana karena faktor pihak ketiga (terkait pemerintahan, imigrasi, pajak, beacukai, dll) yang tidak bisa terprediksi kinerjanya.... (Orang Jepang) seringkali tidak bisa menerima penjelasan tersebut karena beranggapan pihak ketiga tersebut seharusnya melayani perusahaan sebagai customer. (Sumber: data penelitian) 
Pada situasi seperti di atas, staf penutur bahasa Jepang mengungkapkan kesulitan saat harus menjelaskan aturan-aturan atau kebiasaan yang berlaku di Indonesia. Penjelasan staf penutur bahasa Jepang sering kali tidak dapat diterima oleh orang Jepang. Hal ini terjadi karena di Jepang terdapat hierarki yang tegas antara perusahaan dengan customer. JETRO (1999) mengungkapkan bahwa di Jepang, customer diperlakukan layaknya tuhan (Okyakusama wa kamisama desu -- "The customer is a god."). Lebih jauh lagi, JETRO (1999) menuliskan bahwa "Western businesspeople talk about customer orientation and even occasionally say, "The customer is king." But egalitarian Western businesspeople often have a hard time accepting a basic fact of life in the hierarchical Japanese business culture: When it comes to customer demands, the unreasonable is reasonable. One Japanese said, "In the U.S. the customer-vendor relationship is a partnership. In Japan, it is an ownership. " Dari kutipan tersebut dapat dikatakan bahwa perusahaan Jepang sebisa mungkin akan memprioritaskan kepentingan customer. Hal ini berbeda dengan budaya kerja di Indonesia. Di Indonesia customer sering kali cenderung permisif dan fleksibel terhadap keputusan perusahaan/sebuah instansi.

Selain itu, berkaitan dengan uncertainty avoidance index (UAI), Jepang menempati posisi tertinggi ke-8 di dunia dengan indeks cukup tinggi yaitu sebesar 92. Sementara itu, Indonesia menduduki posisi 54 dengan indeks sebesar 46 (Clearly Cultural, n.d.). Tingginya indeks UAI masyarakat Jepang menunjukkan bahwa masyarakat Jepang lebih memilih menghindari situasi yang tidak pasti. Ketidakpastian dan sesuatu yang tidak terstruktur membuat mereka merasa tidak nyaman. Oleh karena itu, masyarakat Jepang meminimalisir ketidakpastian dan menghindari resiko kegagalan dalam menjalankan sesuatu dengan melakukan perencanaan yang matang serta menerapkan aturan-aturan yang ketat. Berlawanan dengan hal tersebut, terdapat kecenderungan orang Indonesia untuk melakukan sesuatu secara lebih spontan atau tanpa perencanaan/persiapan yang lama. 
Sebagai seseorang yang memahami kedua belah pihak, (Indonesia dan Jepang), seorang staf penutur bahasa Jepang tentu sering kali harus berada di posisi terhimpit. Perbedaan budaya kerja antara kedua negara merupakan hal yang tidak dapat dihindari dan tidak dapat diselesaikan sendiri oleh seorang staf penutur bahasa Jepang. Untuk kelancaran aktifitas bisnis di perusahaan, diperlukan sinergi serta kesepakatan bersama antara staf lokal dan ekspatriat Jepang.

\section{SIMPULAN}

Berdasarkan hasil analisis, dapat diketahui bahwa kendala berkomunikasi yang dirasakan oleh staf penutur bahasa Jepang terutama dirasakan saat harus melakukan komunikasi spontan yang dilakukan tanpa persiapan. Kendala tersebut terjadi karena adanya faktor kurangnya pengetahuan bahasa (meliputi senmonyougo, ragam bahasa hormat, dan penggunaan dialek tertentu) dan faktor perbedaan budaya berkomunikasi serta budaya kerja antara kedua negara.

Untuk meningkatkan kualitas dan kompetensi lulusan, penulis memberikan saran untuk pengembangan kurikulum pendidikan vokasional di bidang bahasa Jepang di Indonesia. Program studi vokasional perlu menentukan capaian pembelajaran lulusan secara spesifik, sehingga program studi harus melakukan pemetaan kecenderungan bidang pekerjaan yang digeluti oleh lulusan. Berdasarkan pemetaan tersebut, program studi dapat menentukan materi pembelajaran bahasa Jepang (goi, senmonyougo, keigo) yang sesuai dengan kebutuhan di dunia kerja untuk dimasukkan dalam kurikulum pendidikan vokasional bahasa Jepang.

Muatan materi dasar terkait bisnis dan dunia korporasi perlu diajarkan pada pendidikan vokasional untuk menunjang pengembangan karir lulusan. Materi mengenai perbedaan pola pikir serta budaya kerja di Indonesia dan di Jepang sangat penting untuk dimasukkan dalam kurikulum agar mahasiswa memahami cara berpikir orang Jepang maupun orang 
Indonesia secara sadar. Dengan pengetahuan ini, lulusan dapat menentukan sikap yang tepat dan menghindari kesalahpahaman saat berperan sebagai jembatan komunikasi antara kedua belah pihak.

Soft skill komunikasi mahasiswa perlu diasah melalui kegiatan yang memberikan kesempatan mahasiswa untuk bersinggungan serta berdiskusi dengan orang dari berbagai kalangan dengan latar belakang pendidikan atau budaya yang berbeda, seperti pembelajaran kolaboratif berbasis proyek (project-based learning), pengalaman magang atau organisasi. Hal ini penting dilakukan untuk menumbuhkan daya berpikir kritis, kemampuan mengungkapkan pikiran, kemampuan menyelesaikan masalah, kemampuan bekerjasama, dan kepemimpinan mahasiswa. Melalui metode ini, lulusan dapat berlatih untuk berani mengungkapkan pikiran kepada orang Jepang maupun sesama orang Indonesia secara sopan agar dapat menghindari kesalahpahaman di tempat kerja.

\section{REFERENSI}

Clearly Cultural. (n.d.). Uncertainty avoidance. https://clearlycultural.com/geert-hofstede-culturaldimensions/uncertainty-avoidance-index/

Dwiwardani, W., \& Wahidati, L. (2019). Kebutuhan kompetensi soft skill lulusan program studi bahasa/sastra Jepang di dunia kerja. JLA Uurnal Lingua Applicata), 2(2), 133-147. https://doi.org/10.22146/jla.40511

Hemanona, V., \& Suharyono, S. (2017). ANALISIS PENGARUH FOREIGN DIRECT INVESTMENT TERHADAP COUNTRY ADVANTAGES INDONESIA (Studi Terhadap FDI Amerika Serikat di Indonesia). Jurnal Administrasi Bisnis S1 Universitas Brawijaya, 52(1), 16-25. $\underline{\text { http://administrasibisnis.studentjournal.ub.ac.id/index.php/jab/article }}$ /view/2151

Japan Foundation. (n.d.). N1-N5: Summary of linguistics competence required for each level. https://www.jlpt.jp/e/about/levelsummary.html

JETRO. (1999). Communicating with Japanese in Business. JETRO. https://www.jetro.go.jp/costarica/mercadeo/communicationwith.pdf 
Liliweri, A. (2016). Konfigurasi dasar teori-teori komunikasi antarbudaya. Bandung: Nusa Media.

Nisfullayli, S., et al., (2018). Program Pelatihan Bahasa Asing Terapan: Pemetaan Kompetensi Bahasa Asing untuk Komunikasi Bisnis. Laporan Penelitian Dana Anggaran Masyarakat Tahun Anggaran 2018 Sekolah Vokasi Universitas Gadjah Mada. (Tidak dipublikasikan).

Pratama, I. (2015). PERLUNYA PEMAHAMAN LINTAS BUDAYA DALAM PROSES NEGOSIASI BISNIS (Studi Pada PT. Pratama Jaya Perkasa). Jurnal Administrasi Bisnis S1 Universitas Brawijaya, 24(1), 86028. http://administrasibisnis.studentjournal.ub.ac.id/index.php/jab/article /view/939

Vanuxem, R. (2017, September 19). Five unexpected adjustments you will need to make in your new job. Hays.

https://social.hays.com/2017/09/19/five-adjustments-newjob/\#: :text=Adjustments in your new role,a positive and patient attitude

Visiaty, A. (2020). Unsur budaya dalam komunikasi berbahasa Jepang di dunia korporasi di Indonesia: Kajian konflik interkultural. JLA (Jurnal Lingua Applicata), 4(1), 1-12. https://doi.org/10.22146/jla.57500 